\title{
Evaluating macrolichens and environmental variables as predictors of the diversity of epiphytic microlichens
}

\author{
Journal Article \\ Author(s): \\ Bergamini, Ariel; Stofer, Silvia; Bolliger, Janine; Scheidegger, Christoph \\ Publication date: \\ 2007-09 \\ Permanent link: \\ https://doi.org/10.3929/ethz-b-000059026 \\ Rights / license: \\ In Copyright - Non-Commercial Use Permitted \\ Originally published in: \\ The Lichenologist 39(5), https://doi.org/10.1017/S0024282907007074
}




\title{
Evaluating macrolichens and environmental variables as predictors of the diversity of epiphytic microlichens
}

\author{
Ariel BERGAMINI, Silvia STOFER, Janine BOLLIGER and \\ Christoph SCHEIDEGGER
}

\begin{abstract}
In contrast to the frequently assessed macrolichens, microlichens are rarely considered in biodiversity assessments despite their high species richness. Microlichens require generally a higher species identification effort than macrolichens. Thus, microlichens are more expensive to assess. Here we evaluate if macrolichen richness can be used as an indicator of total and threatened microlichen richness. Furthermore, we tested if different sets of environmental variables (modelled climatic variables, forest structure, altitude, etc.) improve the regression models based on macrolichens only or even replace the macrolichens as predictors. Multiple linear regressions were used to model species richness of microlichens, and Poisson regressions for threatened microlichens.

On 237 forest plots $\left(200 \mathrm{~m}^{2}\right)$ distributed randomly across Switzerland, 77 macrolichens and 219 microlichens occurred. Macrolichen richness was positively related to the richness of microlichens $\left(R_{\text {adj. }}^{2}=0 \cdot 27\right)$ and, in combination with threatened macrolichens as an additional predictor, also to the number of threatened microlichens $\left(R_{\mathrm{dev}}^{2}=0 \cdot 14\right)$. Environmental variables alone and in different combinations explained between 0.20 and $0.41\left(R_{\text {adj. }}^{2}\right.$ ) of the total variation of microlichen richness, and between 0.09 and $0.29\left(R_{\mathrm{dev}}^{2}\right)$ of the total variation of threatened microlichen richness. All models based on environmental variables were considerably improved when macrolichens were included. Furthermore, macrolichen richness turned out to be the most important variable in explaining species richness of all, as well as threatened microlichens. The best models for total microlichen richness reached a $R_{\text {adj. }}^{2}$ of $0 \cdot 56$. Threatened microlichens were more difficult to model with the best model reaching a $R_{\text {dev. }}^{2}$ of $0 \cdot 29$.

We conclude that in biodiversity assessments with scarce resources, lichen sampling could be focused on the better known macrolichens, at least in many temperate lowland and mountain forests. In combination with environmental variables, reliable predictions of microlichen richness can be expected. If the focus is on threatened microlichens, however, models were not reliable and specialized taxonomists are necessary to assess these species in the field.
\end{abstract}

Key words: biodiversity assessment, climate, conservation, forest, indicators, lichens, Red List, species richness.

\section{Introduction}

A very prominent and important research task in conservation biology is to find inexpensive tools to assess species richness or richness of threatened species for a given region, site or habitat (Gaston 1996, EASAC 2005). Interest in this research arose because collecting data on species richness is expensive and time-consuming

A. Bergamini, S. Stofer, J. Bolliger and C. Scheidegger: Swiss Federal Research Institute WSL, Zürcherstrasse 111, CH-8903 Birmensdorf, Switzerland. Email: ariel.bergamini@wsl.ch (e.g. Lawton et al. 1998), especially for small, inconspicuous and species-rich taxa. Ambitious policies such as the 'Target 2010' (see Convention on Biological Diversity at www.biodiv.org/2010-target) have further emphasized the need for species richness indicators (EASAC 2005).

Assuming that different taxa have congruent patterns of species richness, cross-taxon correlations, i.e. correlations between the species number of some well-known and relatively easy-to-measure taxa (=indicator taxa) and the species number of some other, less well-known taxa (=target taxa), have 
been studied intensively (e.g. Lawton et al. 1998; Negi \& Gadgil 2002; Schulze et al. 2004; Schmit et al. 2005). However, the studies so far conducted have been taxonomically biased with beetles, birds, butterflies and vascular plants being considerably over-represented (Wolters et al. 2006). Because lichens exhibit a unique set of special characteristics [symbiontic lifestyle, poikilohydry, lack of a cuticle, generally small thallus size, high susceptibility towards air pollution (Purvis 2000)], these popular indicator groups are not expected to accurately predict lichen species richness (e.g. Pharo et al. 2000) or richness of threatened lichen species. However, lichens are a species-rich group with 13 500-30000 species estimated worldwide (Purvis 2000; see also Feuerer \& Hawksworth 2007). By ignoring them in inventories or biodiversity assessments a large part of diversity will be missed.

On the basis of their growth-form, a very simple classification of lichens into macro(all foliose and fruticose lichens) and microlichens (crustose lichens) is possible. While many macrolichens are rather easy to sample and identify, microlichens generally require much more effort for species identification by specialized taxonomists (Dietrich \& Scheidegger 1996; Ellis \& Coppins 2006). Furthermore, in many regions and habitats, microlichens are considerably richer in species than macrolichens (Dietrich \& Scheidegger 1997; Bergamini et al. 2005; Ellis \& Coppins 2006). The high costs thus associated with the assessment of microlichens is probably the main reason why they are frequently neglected. Macrolichens, on the other hand, are often assessed, sometimes even by trained technicians (McCune et al. 1997; Will-Wolf et al. 2006). It seems therefore obvious to test if macrolichen richness may serve as an indicator for microlichen richness. Bergamini et al. (2005) have shown that the species richness of macrolichens is related to that of microlichens along a land-use gradient in the main biogeographical regions of Europe. The $R^{2}$ value found for epiphytic lichens, however, did not exceed 0.40 which seems too low for practical implementation in nature conservation. So far nothing is known on the relationship between macrolichen richness and the richness of rare or threatened microlichens. If there is a positive correlation between microlichen richness and the number of threatened microlichens, then macrolichen richness may also be positively related to the number of threatened microlichens.

Environmental variables are often much easier to quantify than species numbers of many taxa, and they may be used as a complementary tool when quantifying biodiversity (Berglund \& Jonsson 2001; Gustafsson et al. 2004). Key variables for the distribution of epiphytic forest lichens include forest stand variables (e.g. Berglund \& Jonsson 2001; Gustafsson et al. 2004), variables related to the phorophyte (e.g. Hyvärinen et al. 1992; Uliczka \& Angelstam 1999), other abiotic variables such as altitude (Dietrich \& Scheidegger 1997; Gustafsson et al. 2004), and climatic variables (e.g. Werth et al. 2005; Ellis \& Coppins 2006). Forest-stand, phorophyte-related, and other abiotic variables (referred to here as 'field variables') are often readily available as they are assessed in forest inventories in many countries (e.g. Brassel \& Brändli 1999). Climatic variables of very high spatial resolution $\left(\ll 1 \mathrm{~km}^{2}\right)$ derived from interpolation of climate data, however, are available only for a few countries at present, but may become more widespread in the future. The suitability of interpolated climatic variables to model microlichen richness has not yet been tested (but see Bolliger et al. 2007), and so it is not known whether they are superior to the more traditionally used field variables.

In addition, we hypothesize that the predictions will be much better if we combine macrolichen richness and environmental variables to model microlichen richness than using only environmental variables. The reasoning is that owing to the ecological and physiological similarities of macro- and microlichens, macrolichens will reflect small-scale habitat-variations which are not accounted for by the usually rather 


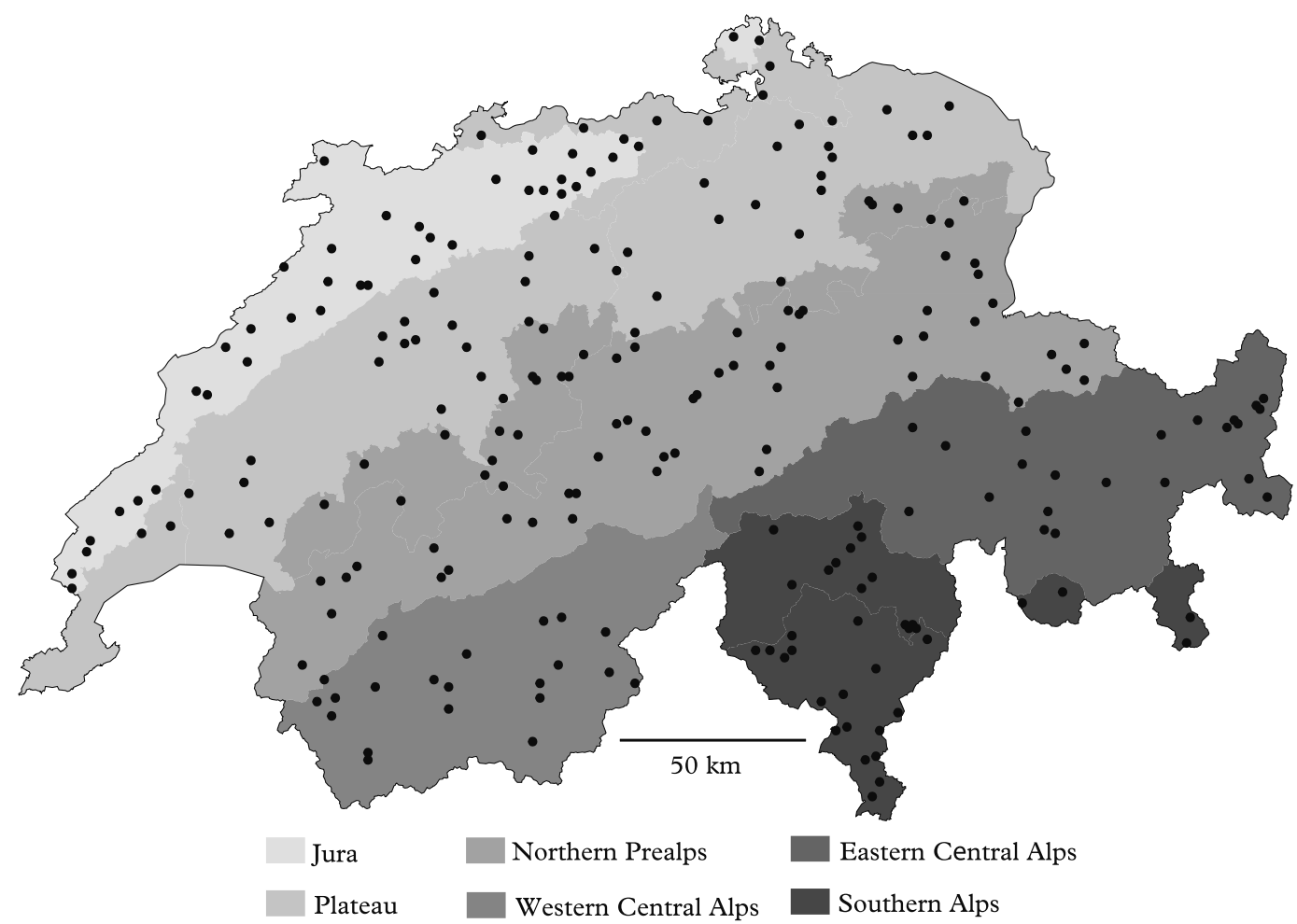

FIG. 1. The six biogeographic regions of Switzerland after Gonseth et al. (2001) and the distribution of the 237 forest plots on which lichens were sampled.

coarse-scale environmental variables (at least from the lichens' view).

The main goal of our study is to test thoroughly the possibility of predicting epiphytic microlichen richness and richness of threatened microlichens by the evaluation of different sets of predictors. Specifically, we have addressed the following questions:

1 Is species richness of macrolichens related to microlichen richness (both total and threatened species)?

2 Which of the two sets of environmental variables (field and climatic variables) better predicts microlichen richness (both total and threatened species)?

3 Does a combination of the two data sets perform better?

4 Does macrolichen richness as an additional predictor improve the models based on environmental variables?

\section{Materials and Methods}

\section{Study area}

The study area included all forested areas of Switzerland, which occupy approximately $30 \%\left(12300 \mathrm{~km}^{2}\right)$ of the total area of the country (Brassel \& Brändli 1999) with an altitudinal range between 200 and $2200 \mathrm{~m}$ a.s.l. The forests in southern Switzerland include chestnut stands [Castanea sativa, nomenclature of vascular plants follows Lauber \& Wagner (2001)], and in northern Switzerland forests are dominated by beech (Fagus sylvatica) in lowland areas (Plateau, see Fig. 1), spruce (Picea abies) in montane and subalpine areas, and larch (Larix decidua) and stone-pine (Pinus cembra) mainly in the higher, central parts of the Alps. Furthermore, planted spruce forests are abundant in many lowland areas (Brassel \& Brändli 1999).

\section{Data}

We used three data sets. The first set consisted of data on lichen species richness which were originally sampled for an inventory of epiphytic lichens in Switzerland between 1995 and 2000 (Scheidegger et al. 
TABLE 1. Environmental variables from the second Swiss forest inventory and from the inventory of Swiss epiphytic lichens (variable 'treesp') used as explanatory variables in the regression models

\begin{tabular}{|c|c|c|c|}
\hline Abbreviation & Description & Data type & $\begin{array}{l}\text { Range of values or } \\
\text { number of classes }\end{array}$ \\
\hline north ${ }^{\star}$ & Northness: cosine of the azimuth & continuous & $-1-1$ \\
\hline east ${ }^{\star}$ & Eastness: sine of the azimuth & continuous & $-1-1$ \\
\hline slope & Slope & continuous & $0-116$ \\
\hline alt & Altitude: elevation above sea level & continuous & $315-2188$ \\
\hline altzone & Altitudinal vegetation zones & factor & 7 classes \\
\hline hist & $\begin{array}{l}\text { Management history: number of years since last } \\
\text { silvicultural operation }\end{array}$ & continuous & $0-109$ \\
\hline prop & Proportion of deciduous trees & ordinal & 4 classes \\
\hline stand & $\begin{array}{l}\text { Stage of stand development: young growth and thicket, } \\
\text { pole wood, young timber, medium timber, old timber, } \\
\text { mixed }\end{array}$ & factor & 6 classes \\
\hline struc & $\begin{array}{l}\text { Stand structure: single-layered, multi-layered, multistorey, } \\
\text { cluster structure }\end{array}$ & factor & 4 classes \\
\hline $\operatorname{graz}^{\star}$ & $\begin{array}{l}\text { Grazing intensity by cattle and/or caprine: not grazed, } \\
\text { extensively grazed, intensively grazed }\end{array}$ & factor & 3 classes \\
\hline sdi & Stand density index & continuous & $20-1633$ \\
\hline treeind & $\begin{array}{l}\text { Number of individual trees with diameter at breast height } \\
(\mathrm{DBH})>12 \mathrm{~cm}\end{array}$ & continuous & $1-42$ \\
\hline treesp & Number of tree species which were colonized by lichens & continuous & $1-7$ \\
\hline basa $^{\star}$ & $\begin{array}{l}\text { Total tree basal area per plot; calculated as: } \\
\Sigma_{\mathrm{i}}\left(\mathrm{DBH}_{\mathrm{i}} / 2\right)^{\wedge} 2 \times \pi\end{array}$ & continuous & $154-17012$ \\
\hline d36 & Number of trees with $\mathrm{DBH}>36 \mathrm{~cm}$ & continuous & $0-8$ \\
\hline picea & Number of individuals of Picea abies with $\mathrm{DBH}>12 \mathrm{~cm}$ & continuous & $0-41$ \\
\hline fagus & Number of individuals of Fagus sylvatica with $\mathrm{DBH}>12 \mathrm{~cm}$ & continuous & $0-23$ \\
\hline abies & Number of individuals of Abies alba with $\mathrm{DBH}>12 \mathrm{~cm}$ & continuous & $0-16$ \\
\hline pinla & $\begin{array}{l}\text { Number of individuals of Pinus cembra and/or Larix decidua } \\
\text { with } \mathrm{DBH}>12 \mathrm{~cm}\end{array}$ & continuous & $0-13$ \\
\hline frax & $\begin{array}{l}\text { Number of individuals of Fraxinus excelsior with } \\
\mathrm{DBH}>12 \mathrm{~cm}\end{array}$ & continuous & $0-8$ \\
\hline acer & $\begin{array}{l}\text { Number of individuals of Acer pseudoplatanus with } \\
\mathrm{DBH}>12 \mathrm{~cm}\end{array}$ & continuous & $0-8$ \\
\hline pinag & $\begin{array}{l}\text { Number of individuals of Pinus sylvestris, } P \text {. mugo, } P \text {. nigra } \\
\text { and } P \text {. strobus with } \mathrm{DBH}>12 \mathrm{~cm}\end{array}$ & continuous & $0-11$ \\
\hline querq & $\begin{array}{l}\text { Number of individuals of Quercus robur, } Q . \text { petraea, } Q . \\
\text { pubescens, and } Q . \text { cerris with } \mathrm{DBH}>12 \mathrm{~cm}\end{array}$ & continuous & $0-6$ \\
\hline
\end{tabular}

*derived variables from second Swiss forest inventory.

2002). From this inventory, all 237 forest plots randomly distributed across the forests of Switzerland (Fig. 1) were used. The area of the horizontal projection of the circular plots was always $200 \mathrm{~m}^{2}$ (radius $=7 \cdot 98 \mathrm{~m}$ ). Thus, on non-horizontal plots the radius had to be increased in the field to hold the projected area constant (for details see Stierlin et al. 1994). Separate lichen species lists per tree species and plot were gathered, including all trees with a minimum diameter at breast height $(\mathrm{DBH})$ of $12 \mathrm{~cm}$. Trees were searched for lichens from ground level up to $170 \mathrm{~cm}$ stem height. According to their growth form and red list status (Scheidegger et al. 2002), all lichen species were classified as macroor microlichens and as either threatened (all critically endangered, endangered and vulnerable species) or not threatened (all nearly threatened species and all species of least concern). From this data set we also gathered the total number of tree species colonized by lichens (with a minimum $\mathrm{DBH}$ of $12 \mathrm{~cm}$ ).

A second data set consisted of various environmental variables which were originally sampled for the second national forest inventory between 1993 and 1995 on the same plots as the lichen data (Stierlin et al. 1994; Brassel \& Brändli 1999). From these variables, we selected 20 (some of them slightly modified, see Table 1), which have been hypothesized or known from personal experience or literature to be of importance for lichen species richness.

A third data set was composed of modelled climatic variables and included thermic variables (summer frost 
TABLE 2. Modelled climatic variables used as explanatory variables in the regression models

\begin{tabular}{ll}
\hline Abbreviation & \\
\hline dgd & $\begin{array}{l}\text { Degree days: sum of the days above a temperature threshold of } 5^{\circ} \mathrm{C} \text { calculated for an entire } \\
\text { year } \\
\text { Summerfrost frequency: expresses the number of frost events during the frost-sensitive time of } \\
\text { the year }\end{array}$ \\
$\begin{array}{l}\text { Mean monthly precipitation sum } \\
\text { prec }\end{array}$ & $\begin{array}{l}\text { Water budget in July: calculated as the difference between the precipitation sum and the } \\
\text { potential evapotranspiration in July } \\
\text { rmar }\end{array}$ \\
$\begin{array}{l}\text { Radiation in March: based on yielding in potential solar radiation for given altitudes for a } \\
\text { surface perpendicular to the incoming sunlight. Shading of mountain chains and } \\
\text { adjustments to slope and aspect are taken into account. }\end{array}$ \\
$\begin{array}{l}\text { Radiation in July: (see 'radiation in March') } \\
\text { kig } \\
\text { julc }\end{array}$ \\
$\begin{array}{l}\text { Gams angle: based on precipitation and temperature regimes at given elevations } \\
\text { July cloudiness }\end{array}$
\end{tabular}

frequency, degree day sum), hygric variables (mean monthly precipitation sum, water budget in July), and measures for continentality (global radiation in March and July, Gams angle, and July cloudiness, Table 2). All these variables are available as grid maps, based on spatially interpolated data from standardized meteorological recordings (considered time period: 1961-1990) derived from the national network and digital elevation models on a $25 \mathrm{~m}$ resolution (for details see Zimmermann \& Kienast 1999; Bolliger et al. 2000). To characterize the local climate and its variability around each plot, we calculated the mean, the standard deviation, and the minimum and maximum of each variable within one square kilometre with the respective plot as the centre. However, the minimum, the maximum and the mean were often highly correlated. If the correlation coefficient (Spearman's rank) was above 0.95 , only the mean for the regression models was used which reduced the number of climatic variables from 32 to 20 .

The resulting total of 43 variables (Tables 1 and 2) were arranged in three groups: (1) macrolichens; (2) field variables (data from the second data set together with the number of trees which were colonized by lichens from the first set); (3) the modelled climatic variables. The variables were then used to develop regression models.

\section{Regression models}

Linear regressions were used to predict microlichen species richness. We tested seven different combinations of explanatory variables: (1) field variables only, (2) climatic variables only, (3) macrolichens only, (4) macrolichens and field variables, (5) macrolichens and climatic variables, (6) field variables and climatic variables, (7) macrolichens, field variables and climatic variables.

All continuous variables were $\log _{10}$ transformed, count data square root transformed, and for proportions the arcsin transformation was applied ("first aid transformations' after Tukey, see Stahel 2002). To reduce the number of explanatory variables, the $R$-function 'stepAIC' (direction='both', $R$-package 'MASS') was first applied and then all variables with $P$-values $>0.05$ were stepwisely removed. Finally, all eliminated variables were again stepwisely added to the reduced model, but only included if their $P$-value was $\leq 0.05$ and their variance inflation factors (function 'vif' in the $R$-package 'car') $\leq 10$. This was done because the significance or importance of a variable in the reduced model may be very different from its significance in the full model (Sokal \& Rohlf 1995), i.e. a formerly not significant variable may become significant in the reduced model. To compare the different models we used the adjusted $R^{2}$ (Montgomery et al. 2001).

There were many plots without any threatened microlichens. Therefore, we applied generalized linear models to implement Poisson regressions to model the number of red-listed microlichens. We used the same combinations of groups of explanatory variables as in the linear case, but the three factors 'altzone', 'stand', and 'struc' were omitted because of the very low proportion of plots containing threatened microlichens at some factor levels which led to very unstable models. Because threatened microlichens may occur at the same places as threatened macrolichens, threatened macrolichens were included in the first group of explanatory variables which now consisted of two variables. To reduce the number of variables, the same procedure as for the ordinary linear regressions was applied. Because the usual $R^{2}$-measure is not applicable in GLMs, we applied an adjusted pseudo- $R^{2}$ measure after Mittelböck \& Waldhör (2000) to compare the different models, i.e. $R_{\mathrm{dev}}^{2}=1-[($ Residual deviance $+\mathrm{k} / 2) /$ Null deviance] where $\mathrm{k}$ is the number of explanatory variables in the model. Omitting the term $\mathrm{k} / 2$ in this formula results in an unadjusted $R^{2}$ comparable to the unadjusted $R^{2}$ of the normal linear regression. Assumptions of regression were tested in the same way as for the linear regressions. 
Plots with missing values for some of the environmental variables were omitted from all regressions. The total number of replications was thus only 222 instead of 237. All final models fulfilled all assumptions of regression analyses and there were no indications of curvilinear relationships in the final models. Furthermore, visual inspection of the variograms of the residuals from the final regression models was used for checking for spatial autocorrelation of the residuals. All calculations were done in R 2.3.0 ( $\mathrm{R}$ Development Core Team 2006). For the regressions and the residual analyses we used the function 'f.reg' which was written by W. Stahel (Seminar for Statistics, ETH Zurich); for the variograms we used the $R$-function 'variog' from the geoR-package (version 1.5-7).

\section{Model evaluation}

A bootstrap approach was used to evaluate the final regression models (Efron \& Tibshirani 1993). We first generated 1000 bootstrap samples of the 222 plots used for the regressions. Each bootstrap sample was considered as a 'new' dataset; it was then used as new input data for the calculation of new regressions. In these new regressions, we did not perform a variable selection procedure again, but chose the variables already selected in the model which we intended to evaluate. Thus, this procedure delivered for each model 1000 new $R^{2}$ values $\left(R_{\mathrm{A}}^{2}\right.$; for the linear regressions these are just the normal, unadjusted $R^{2}$ values, for the Poisson regressions these are the unadjusted $R_{\mathrm{dev}}^{2}$. values) and 1000 sets of new regression coefficients. These regression coefficients were then applied on the orginal data set which led again to a $R^{2}$ value $\left(R_{\mathrm{B}}^{2}\right)$. The mean of the differences between the $R_{\mathrm{A}}^{2}$ and $R_{\mathrm{B}}^{2}$ values is an estimation of the optimism of the original model. The $R^{2}$ value from the model to be evaluated less the difference between $R_{\mathrm{A}}^{2}$ and $R_{\mathrm{B}}^{2}$ delivers an optimism-corrected $R^{2}$ value $\left(R_{\text {boot }}^{2}\right)$. This $R_{\text {boot }}^{2}$ can be interpreted as an estimate on how the model would perform if new data were available.

\section{Results}

A total of 296 lichen species were found in the 237 plots, comprising 77 macrolichens and 219 microlichens. Only 13 plots contained no lichens at all. The number of lichens per plot varied between 1 and 55 (macrolichens: 0-25, microlichens: 1-37), and the mean number of lichens per plot was 19.14 (macrolichens 5.65, microlichens 13.49). The number of threatened microlichens per plot varied between 0 and 4 $($ mean $=0 \cdot 44)$. The spatial distribution of total and threatened microlichen richness is depicted in Figs 2A and 4A. On the 237 plots we found 34 different tree species which were colonized by lichens. The mean number of tree species per plot was $2 \cdot 15$ (range: 1-7). The most frequent tree species were Picea abies (132 plots), Fagus sylvatica (78 plots), Abies alba (64 plots), Fraxinus excelsior (32 plots), Larix decidua (29 plots), Acer pseudoplatanus (29 plots), Pinus sylvestris (19 plots).

\section{Regression models}

All seven models found for the different combinations of groups of variables for explaining species richness of microlichens were highly significant $(P<0 \cdot 001$, Table 3$)$. The macrolichen richness alone explained more than a quarter of the total variation in microlichen richness $\left(R_{\text {adj. }}^{2}=0 \cdot 27\right)$. The model based only on the climatic variables had the lowest $R_{\text {adj. }}^{2}(=0 \cdot 20)$ of all models. The large amount of unexplained variation in these two models resulted in a low spatial resolution of modelled numbers of microlichens (Fig. 2B \& C), and a low correspondence between observed and modelled numbers of microlichens (Fig. 3A \& B). The model based on the field variables only performed better than both the macrolichen and the climate model $\left(R_{\text {adj. }}^{2}=0 \cdot 45\right.$, Figs $2 \mathrm{D}$ \& 3C). The model including macrolichens and the climatic variables, and the model including field and climatic variables explained similar amounts of variation $\left(R_{\text {adj. }}^{2}=0.37\right.$ and 0.42 , respectively). Suprisingly, both of these models performed worse than the model based only on the field variables. Starting the selection procedure with the macrolichens and the field variables, or with the macrolichens, the field variables and the climatic variables resulted in two models with the highest and identical $R_{\text {adj. values }}^{2}(0.56)$. The spatial pattern of predicted values of the best model was quite close to the observed pattern (Fig. 2E) and the correspondence between observed and modelled values was clearly improved (Fig. $3 \mathrm{D})$. The following field variables were positively related to the number of microlichens in the two models with the highest $R_{\text {adj. }}^{2}$ : number of tree species which were colonized 
A

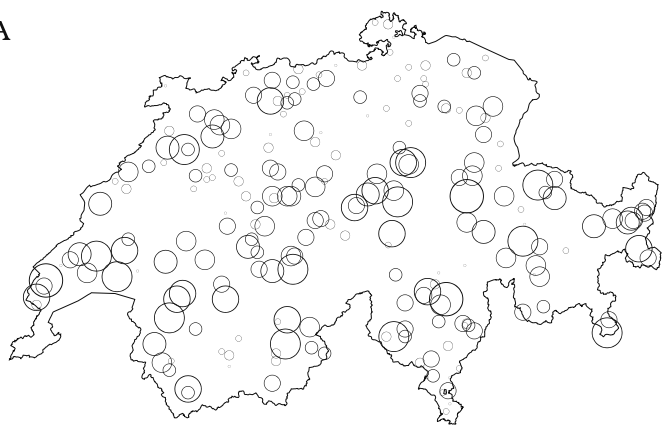

c
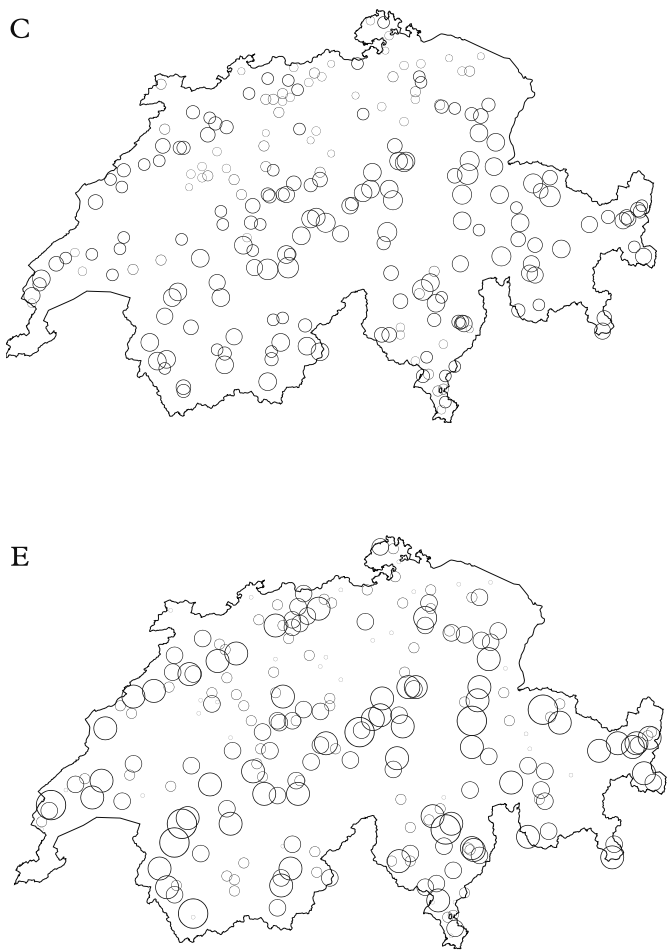
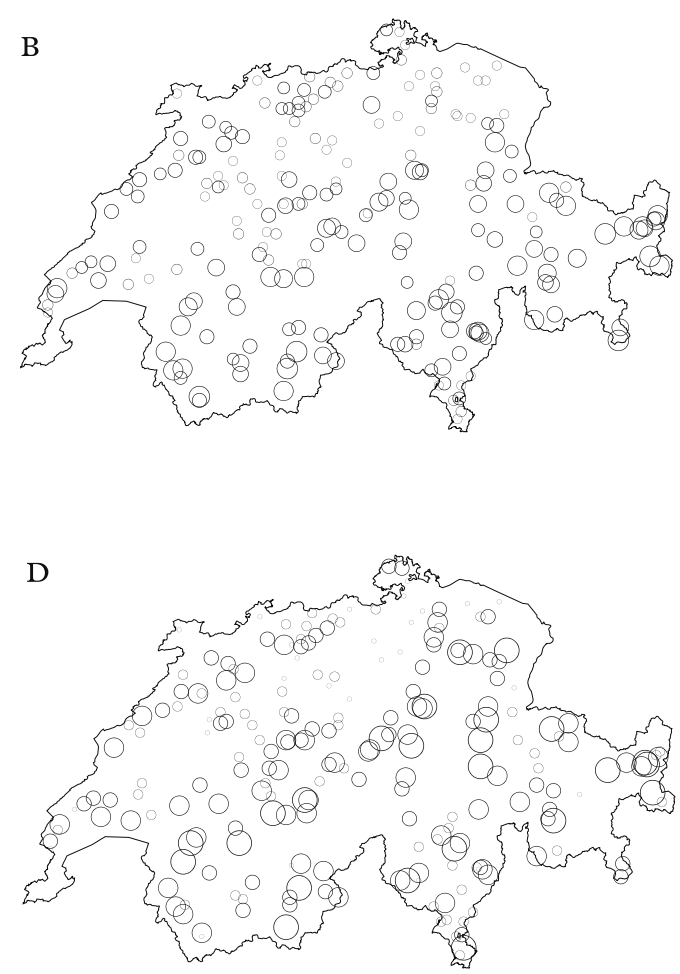

FIG. 2. Observed and modelled richness of microlichens. A, observed number of microlichens; B, fitted number of microlichens based on the model including only macrolichen richness; C, fitted number of microlichens based on the model including only climatic variables; D, fitted number of microlichens based on the model including only field variables; E, fitted number of microlichens based on field variables and macrolichens (best model). Maximum radius of circles corresponds to 37 microlichens, minimum radius to 1 .

by lichens, total basal area of trees, proportion of deciduous trees, and the number of individuals of Acer pseudoplatanus. The number of individuals of Quercus spp. and Pinus spp. were negatively correlated to the number of microlichens. In the macro- lichens and field variables model there were some additional weak negative effects of the total number of individual trees, northness and the number of trees with $\mathrm{DBH}>36 \mathrm{~cm}$, and a weak positive effect of the number of individuals of Fagus sylvatica. Three 
TABLE 3. Summary of simple and multiple linear regressions with the number of microlichens as response variable in all models

\begin{tabular}{|c|c|c|c|}
\hline Explantory variables & Model (Standardized regression coefficients, F-values) & $R_{\text {adj. }}^{2}$ & $R_{\text {boot }}^{2}$ \\
\hline Only macrolichens & $\operatorname{macro}(0 \cdot 52,81 \cdot 8)$ & $0 \cdot 27$ & $0 \cdot 27$ \\
\hline Only field variables & $\begin{array}{l}\text { alt }(0 \cdot 63,84 \cdot 1) \text {, basa }(0 \cdot 51,46 \cdot 0) \text {, treesp }(0 \cdot 32,26 \cdot 9) \text {, picea } \\
(-0 \cdot 29,17 \cdot 4) \text {, pinla }(-0 \cdot 20,10 \cdot 0) \text {, abies }(-0.19,9 \cdot 1) \text {, east } \\
(0 \cdot 14,7 \cdot 1) \text {, pinag }(-0 \cdot 13,5 \cdot 4) \text {, stand }(-, 3 \cdot 2) \text {, struc }(-, 2 \cdot 8)\end{array}$ & $0 \cdot 41$ & $0 \cdot 36$ \\
\hline Only climatic variables & $\begin{array}{l}\text { rjul_m }(0 \cdot 57,19 \cdot 4), \text { prec_s }(0 \cdot 24,8 \cdot 7) \text {, wbju_s }(-0 \cdot 48,8 \cdot 0) \text {, } \\
\text { rmar_m }(-0 \cdot 34,7 \cdot 5), \text { rjul_s }(0 \cdot 43,6 \cdot 6) \text {, kig_s }(0 \cdot 20,4 \cdot 8)\end{array}$ & $0 \cdot 20$ & $0 \cdot 16$ \\
\hline $\begin{array}{l}\text { Macrolichens and field } \\
\text { variables }\end{array}$ & $\begin{array}{l}\text { macro }(0 \cdot 76,178 \cdot 8) \text {, treesp }(0 \cdot 27,25 \cdot 2) \text {, basa }(0 \cdot 47,16 \cdot 3) \text {, } \\
\text { pinag }(-0 \cdot 17,13 \cdot 4) \text {, acer }(0 \cdot 15,10 \cdot 2) \text {, prop }(0 \cdot 18,9 \cdot 6) \text {, } \\
\text { querq }(-0 \cdot 14,8 \cdot 1) \text {, pinla }(-0 \cdot 12,5 \cdot 8) \text {, fagus }(0 \cdot 13,5 \cdot 4) \text {, } \\
\text { treeind }(-0 \cdot 18,4 \cdot 4) \text {, north }(-0 \cdot 09,4 \cdot 1) \text {, d36 }(-0 \cdot 20,3 \cdot 9) \text {, } \\
\text { stand }(-, 3.4)\end{array}$ & $0 \cdot 56$ & 0.53 \\
\hline $\begin{array}{l}\text { Macrolichens and } \\
\text { climatic variables }\end{array}$ & $\begin{array}{l}\text { macro }(0 \cdot 61,54 \cdot 7) \text {, prec_s }(0 \cdot 27,13 \cdot 9), d g d \_m(0 \cdot 40,11 \cdot 2) \text {, } \\
\text { wbju_m }(0 \cdot 17,8 \cdot 9), \text { wbju_s }(-0 \cdot 43,7 \cdot 8) \text {, rjul_s }(0 \cdot 39,6 \cdot 7) \text {, } \\
\text { rjul_m }(0 \cdot 44,6 \cdot 6), \text { rmar_m }(-0 \cdot 29,5 \cdot 7)\end{array}$ & $0 \cdot 35$ & $0 \cdot 34$ \\
\hline $\begin{array}{l}\text { Field and climatic } \\
\text { variables }\end{array}$ & $\begin{array}{l}\text { kig_m }(0 \cdot 65,50 \cdot 1) \text {, basa }(0 \cdot 36,42 \cdot 2) \text {, prec_m }(0 \cdot 47,36 \cdot 3) \text {, } \\
\text { treesp }(0 \cdot 28,25 \cdot 5) \text {, prop }(0 \cdot 33,21 \cdot 6) \text {, rjul_s }(0 \cdot 40,8 \cdot 0) \text {, east } \\
(0 \cdot 14,7 \cdot 3), \text { wbju_s }(-0 \cdot 29,4 \cdot 6), j u l c \_m(-0 \cdot 12,4 \cdot 4)\end{array}$ & $0 \cdot 39$ & $0 \cdot 36$ \\
\hline $\begin{array}{l}\text { Macrolichens, field and } \\
\text { climatic variables }\end{array}$ & $\begin{array}{l}\text { macro }(0 \cdot 58,73 \cdot 8) \text {, treesp }(0 \cdot 30,32 \cdot 8) \text {, prop }(0 \cdot 33,31 \cdot 2) \text {, } \\
\text { basa }(0 \cdot 27,25 \cdot 6) \text {, rjul_s }(0 \cdot 37,10 \cdot 3) \text {, rmar_m }(-0 \cdot 30,9 \cdot 3) \text {, } \\
\text { rjul_m }(0 \cdot 34,8 \cdot 5) \text {, querq }(-0 \cdot 14,8 \cdot 0) \text {, wbju_s }(-0 \cdot 30,7 \cdot 3) \text {, } \\
\text { pinag }(-0 \cdot 12,7 \cdot 1) \text {, acer }(0 \cdot 13,6 \cdot 8) \text {, stand }(-, 3 \cdot 0)\end{array}$ & $0 \cdot 56$ & $0 \cdot 53$ \\
\hline
\end{tabular}

*Abbreviations of explanatory variables as indicated in Tables $1 \& 2$ with the exception of 'macro' which is the number of macrolichens. Climatic variables are in italics. The ending of the climatic variables indicates if the mean (_m) or the standard deviation ( $(\mathrm{s})$ of the respective variable was used. For factors there are no standardized regression coefficients. All models are highly significant $(P<0 \cdot 001) . R_{\mathrm{adj}}^{2}$ : adjusted $R^{2} ; R_{\mathrm{Boot}}^{2}$ : 'optimism-corrected' $R^{2}-$ values.

variables related to radiation and one to the water budget in July significantly affected the number of microlichens in the best model with climatic variables. Furthermore, the number of macrolichen species turned out to be the most important variable in all models which included this variable (largest F-values, Table 3). The inclusion of macrolichens in the models resulted in a relative increase in $R_{\text {adj. }}^{2}$ of 36 to $75 \%$.

The models found for explaining species richness of threatened microlichens were all highly significant $(P<0.001$, Table 4$)$, but

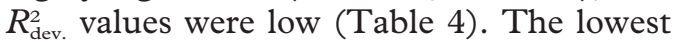
$R_{\text {dev. }}^{2}$ (0.09) was observed for the model based on the climatic variables. The number of macrolichens and the number of threatened macrolichens were both positively related to the number of threatened microlichens. However, the $R_{\mathrm{dev}}^{2}$ was quite low $(0 \cdot 14)$. The highest $R_{\mathrm{dev}}^{2}(0 \cdot 29)$ was observed for the model including macrolichens, three field variables and eight climatic variables. A visual comparison between the observed and the fitted values showed a similar pattern with higher values in the southern Alps, the eastern and western-central Alps and the northern Prealps (Fig. 4A \& B), but, as shown in Figure 5, the correspondence between observed and modelled values was low. As for total microlichen richness, the proportion of deciduous trees and the number of tree species which were colonized by lichens had a positive effect. Significant climatic variables included thermic variables (summer frost frequency), hygric variables (mean monthly precipitation sum, water budget in July) and measures for continentality (radiation in March and July, July cloudiness). Models which included the number of macrolichens performed considerably better than models without that variable (relative increase in $R_{\mathrm{dev}}^{2}$ when macrolichens were included: $21-122 \%$ ). 


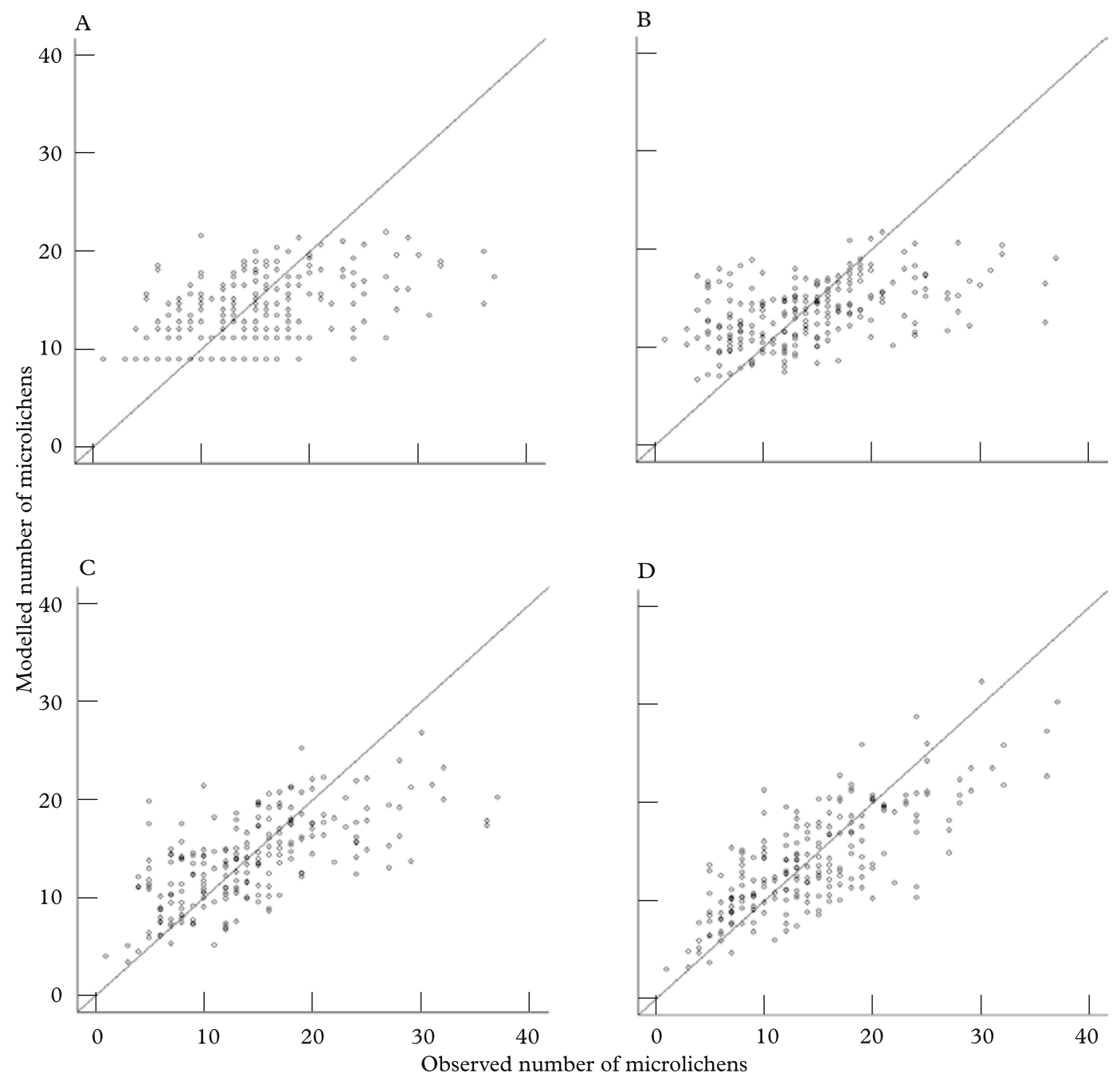

FIG. 3. Relationships between modelled and observed richness of microlichens. A, modelled number of microlichens based on macrolichen richness only; B, modelled number of microlichens based on climatic variables only; C, modelled number of microlichens based on field variables only; D, modelled number of microlichens based on field variables and macrolichen richness. In a perfect model all points would be located on the 1:1 line.

\section{Model evaluation and spatial autocorrelation}

The $R_{\text {boot }}^{2}$ values of the linear regressions were between $0 \%$ and $20 \%$ lower than the $R_{\text {adj. }}^{2}$ values (Table 3). For the best model, the $R_{\text {boot }}^{2}$ was $5 \cdot 4 \%$ lower than the $R_{\text {adj. }}^{2}$ value but still high $(0 \cdot 53)$. There was no spatial autocorrelation (not shown) observed in the variogram of the residuals of the two best linear regression models. In all other models, except for the macrolichen-only model, the variograms showed very weak autocorrelations. In the macrolichen-only model, residuals were autocorrelated. However, since the effect of the macrolichens was highly significant $(P<0.001)$, we suppose that the model would still be significant after accounting for spatial autocorrelation (Fortin \& Dale 2005). 
TABLE 4. Summary of multiple Poisson regressions with the number of threatened microlichens as the response variable in all models ${ }^{\star}$

\begin{tabular}{|c|c|c|c|}
\hline Explantory variables & Model (Standardized regression coefficients, $\chi^{2}$-values) & $R_{\mathrm{dev}}^{2}$ & $R_{\text {Boot }}^{2}$ \\
\hline Only macrolichens & macro $(0 \cdot 43,11 \cdot 2)$, macrorl $(0 \cdot 23,7 \cdot 9)$ & $0 \cdot 14$ & $0 \cdot 12$ \\
\hline Only field variables & $\begin{array}{l}\text { alt }(0 \cdot 94,22 \cdot 4) \text {, prop }(0 \cdot 51,9 \cdot 6) \text {, treesp }(0 \cdot 38,8 \cdot 6) \text {, basa } \\
(0 \cdot 33,6 \cdot 2) \text {, slope }(-0 \cdot 34,5 \cdot 2) \text {, east }(0 \cdot 24,4 \cdot 4) \text {, pinla } \\
(-0 \cdot 29,4 \cdot 4) \text {, fagus }(-0 \cdot 29,4 \cdot 0)\end{array}$ & $0 \cdot 14$ & $0 \cdot 06$ \\
\hline Only climatic variables & $\begin{array}{l}\text { rjul_s }(0 \cdot 74,7 \cdot 6), \text { rjul_m }(0 \cdot 32,7 \cdot 5), \text { wbju_s }(-0 \cdot 62,4 \cdot 5) \text {, } \\
\text { prec_s }(0 \cdot 30,4 \cdot 3)\end{array}$ & $0 \cdot 09$ & $0 \cdot 05$ \\
\hline $\begin{array}{l}\text { Macrolichens and field } \\
\text { variables }\end{array}$ & macro $(0.81,37 \cdot 7)$, pinla $(-0.38,8 \cdot 8)$, treesp $(0.31,7 \cdot 1)$ & $0 \cdot 17$ & $0 \cdot 13$ \\
\hline $\begin{array}{l}\text { Macrolichens and } \\
\text { climatic variables }\end{array}$ & $\begin{array}{l}\text { macro }(0 \cdot 86,24 \cdot 7), d g d \_m(1 \cdot 05,16 \cdot 6), \text { rjul_m }(1 \cdot 11,10 \cdot 1) \text {, } \\
\text { prec_s }(0 \cdot 43,9 \cdot 4), w b j u \_m(0 \cdot 33,7 \cdot 3), \text { rmar_m }(-0 \cdot 62,7 \cdot 1)\end{array}$ & $0 \cdot 20$ & $0 \cdot 14$ \\
\hline $\begin{array}{l}\text { Field and climatic } \\
\text { variables }\end{array}$ & $\begin{array}{l}\text { rjul_m }(1 \cdot 10,23 \cdot 2) \text {, rjul_s }(1 \cdot 46,18 \cdot 1) \text {, prop }(0 \cdot 61,14 \cdot 1) \text {, } \\
\text { prec_s }(0 \cdot 53,11 \cdot 3) \text {, fagus }(-0 \cdot 47,9 \cdot 2) \text {, julc_m }(-0 \cdot 57,8 \cdot 5) \text {, } \\
\text { wbju_m }(0 \cdot 97,8 \cdot 5) \text {, treesp }(0 \cdot 36,7 \cdot 7) \text {, slope }(-0 \cdot 46,6 \cdot 9), \\
\text { basa }(0 \cdot 32,6 \cdot 1), \text { rmar_m }(-0 \cdot 70,5 \cdot 8) \text {, wbju_s }(-0 \cdot 67,4 \cdot 5) \text {, } \\
\text { prec_m }(-0 \cdot 53,4 \cdot 3)\end{array}$ & $0 \cdot 24$ & $0 \cdot 11$ \\
\hline $\begin{array}{l}\text { Macrolichens, field and } \\
\text { climatic variables }\end{array}$ & $\begin{array}{l}\text { macro }(0 \cdot 90,22 \cdot 8) \text {, wbju_m }(1 \cdot 24,11 \cdot 4) \text {, rjul_m }(0 \cdot 78,11 \cdot 4) \text {, } \\
\text { prop }(0 \cdot 48,11 \cdot 0), \text { prec_s }(0 \cdot 45,9 \cdot 5) \text {, slope }(-0 \cdot 53,8 \cdot 9) \text {, rjul_s } \\
(0 \cdot 62,6 \cdot 6), s f r o \_m(-0 \cdot 40,6 \cdot 6), \text { prec_m }(-0 \cdot 68,6 \cdot 3), \\
\text { rmar_m }(-0 \cdot 63,5 \cdot 7), \operatorname{treesp}(0 \cdot 86,5 \cdot 5), j u l c \_m(-0 \cdot 42,4 \cdot 2)\end{array}$ & $0 \cdot 29$ & $0 \cdot 19$ \\
\hline
\end{tabular}

*Abbreviations of explanatory variables as indicated in Tables $1 \& 2$. with the exception of 'macro', which is the number of macrolichens, and 'macrorl', which is the number of threatened macrolichens. The ending of the climatic variables indicates whether the mean (_m) or the standard deviation (_s) of the respective variable was used. Climatic variables are in italics. All models are highly significant $(P<0 \cdot 001)$. $R_{\text {dev }}^{2}$ : adjusted $R^{2}$ after

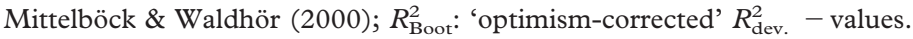
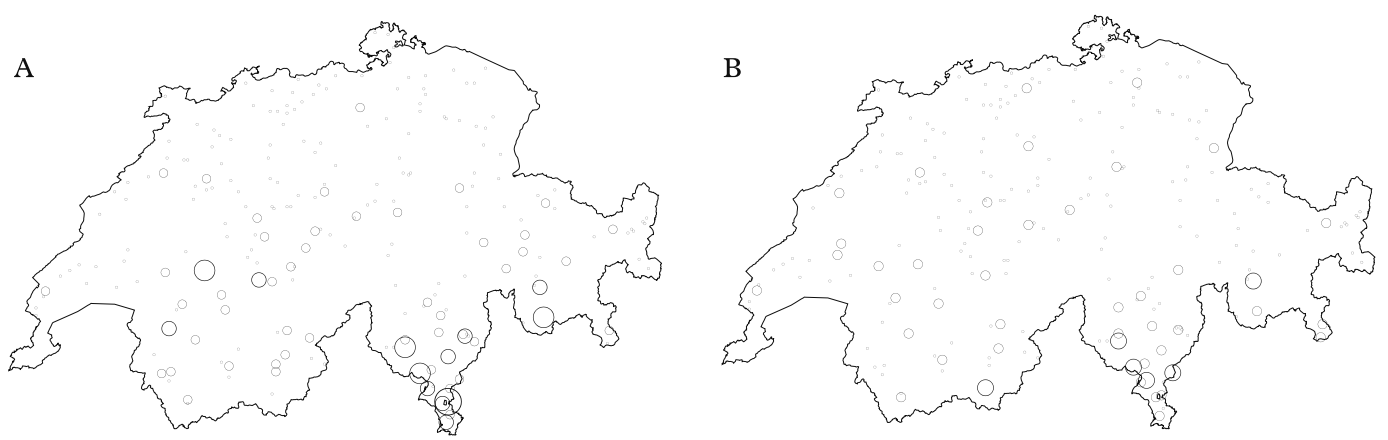

FIG. 4. Observed and modelled richness of threatened microlichens. A, observed number of threatened microlichens; B, fitted number of threatened microlichens based on macrolichens, field and climatic variables (best model). Maximum radius of circles corresponds to 4 threatened microlichens, minimum radius to 0 .

The $R_{\text {boot }}^{2}$ values from the Poisson regressions were between $14 \%$ and $57 \%$ lower than the $R_{\text {dev }}^{2}$ values (Table 3 ). For the best model, the $R_{\text {boot }}^{2}$ value was $0 \cdot 19$ and thus $34.5 \%$ lower than the $R_{\mathrm{dev}}^{2}$. There was spatial autocorrelation of the residuals in all but the two models with the highest $R_{\mathrm{dev}}^{2}$ values. Again, in the macrolichen-only model, effects of both variables were highly significant $(P<0 \cdot 0035)$. Thus, it is unlikely that accounting for spatial autocorrelation would change the result. 


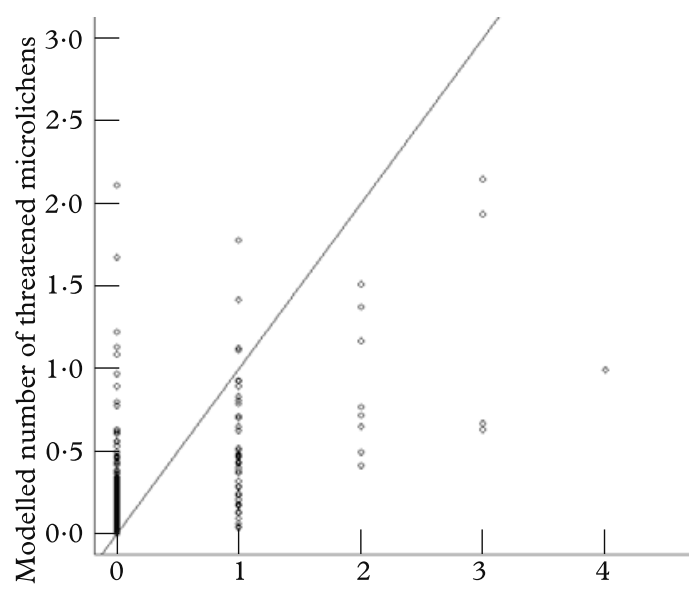

Observed number of threatened microlichens

FIG. 5. Relationship between modelled number of threatened microlichens (based on field and climatic variables, and macrolichen richness) and observed richness of threatened microlichens. In a perfect model all points would be located on the 1:1 line.

\section{Discussion}

We have shown that the species richness of epiphytic macrolichens was significantly related to the species richness of total and threatened microlichens. The explained variation of both total and threatened microlichen richness based on macrolichens only was, however, rather low and certainly too low to propose macrolichens alone as a surrogate for microlichens. As hypothesized, the models based only on environmental variables (field and/or climatic variables) were considerably improved by adding macrolichen richness as an additional predictor. In a recent meta-analysis, Wolters et al. (2006) revealed an average correlation coefficient of 0.374 between the species richness of different taxa. This results in a $R^{2}$ of only $0 \cdot 14$. Thus, macrolichens performed better than an average species richness indicator. The better performance of macrolichens provides some evidence for the sometimes hypothesized advantage of using indicator and target taxa which share ecological requirements and life-history traits (Beccaloni \& Gaston 1995; Bergamini et al. 2005).

Relationships between richness of microlichens and several indicator taxa were studied by Berglund \& Jonsson (2001). They found polyporous and corticoid fungi to be good indicators of microlichen richness with relationships very similar to the ones we found here between macro- and microlichen richness. Interestingly, richness of mosses and liverworts, which share several life history characteristics with lichens (e.g. poikilohydry, lack of true roots), was not related to microlichen richness in that study (see also Pharo \& Beattie 1997).

An alternative explanation for the positive relationship between macro- and microlichen richness invokes species-area relationships. Because in our study the number of trees per plot was not standardized, the relationship between macro- and microlichens could simply be caused by a positive species-area relationship. At least for total microlichen richness, however, tree basal area was included in the best models and macrolichen richness was still highly significant. We therefore conclude that the positive relationship between macro- and microlichen richness is not due to a positive species-area relationship but reflects similar ecological requirements.

The relationship between micro- and macrolichens, however, was far from perfect, indicating considerable differences between the two groups. For example, size and age of trees may have different effects on richness or frequency of macro- and microlichens (Ihlen et al. 2001; Ellis \& Coppins 2006). In general, succession of epiphytic lichen communites starts with crustose lichens, followed by foliose lichens and, eventually, fruticose lichens (Ochsner 1927; Barkman 1958; Ellis \& Coppins 2006). At least in one of the two best models the number of trees with $\mathrm{DBH}>36 \mathrm{~cm}$ had a negative effect on microlichen richness, which can be seen as a confirmation of the general successional trend. However, there are also numerous exceptions to this general trend (Ochsner 1927; Barkman 1958). A typical habitat dominated by various ombrophobous and aerohygrophilous microlichens consists of dry bark of forest trees in old growth stands (Barkman 1958; Holien 1998). Ellis \& Coppins (2006) showed that effects of 
precipitation differ between several functional groups of lichens with microlichens becoming less frequent in forest stands in wetter sites. Land-use intensity is another variable which may affect macro- and microlichens differently (Stofer et al. 2006).

The climatic variables were weak predictors of the species richness of microlichens. There are several explanations for this low performance:

1 There may be a mismatch between modelled climatic variables and the 'real' climate at the plot locations due to modelling errors. A separate regression analysis, however, has shown that the number of macrolichens can be modelled quite accurately by the climatic variables $\left(R_{\text {adj. }}^{2}=0.61\right.$, model with six climatic variables). The climatic variables seem therefore quite reasonable to characterize the climatic conditions at the plot scale.

2 The microlichens may be more susceptible to microclimatic conditions than the macrolichens. For example, bark fissures often contain specialized microlichens (Barkman 1958), but hardly any macrolichens.

3 Dispersal limitation has been shown to severely constrain distribution of many lichen species (Sillett et al. 2000; Hedenås et al. 2003; Löbel et al. 2006). If microlichen distribution in general is strongly dispersal-limited, then it is impossible to predict reliably microlichen richness by means of climatic variables only because climatically suitable places may not be occupied.

4 Microlichen richness is controlled by factors not correlated with climate such as variability of tree species and age (or diameter) leading to greater environmental heterogeneity within plots. For example, it is well known that several properties of the bark such as $\mathrm{pH}$ or water capacity change as the trees grow older (Barkman 1958).

Nevertheless, models based on climatic variables have proven to be very useful for modelling the distribution of single micro- lichen species due to their dependence on macroclimatic conditions (e.g. Graphis scripta and Lecanora cadubriae, see Bolliger et al. 2007).

In contrast to the climatic variables, the field variables performed much better. The most important field variables for both total and threatened microlichen species richness included variables such as total tree basal area per plot, number of tree species which are colonized by lichens, proportion of deciduous trees as well as proportions of various tree species. These or closely related variables have been used in many ecological studies and shown to affect lichen species distribution or species richness patterns (e.g. Barkman 1958; Hyvärinen et al. 1992; Uliczka \& Angelstam 1999; Gustafsson et al. 2004).

Generally, the models for threatened microlichens explained considerably less of the variation than models for all microlichens. Even the best model had a rather low $R_{\mathrm{dev}}^{2}$ value. In addition to the low $R_{\mathrm{dev}}^{2}$. values, the $R_{\text {boot }}^{2}$ values were also proportionally much lower than for the models of all microlichens, mainly because of the high proportion of plots without any threatened species. Therefore, regression coefficients of the bootstrap samples may have been strongly dependent on the number of plots in these samples which contained threatened species, leading to low performance of models using the original 222 plots but parameterized with these bootstrap coefficients. Nevertheless, the best model found may still be useful to enhance detection probabilities for endangered microlichens by a modelbased stratification of the sampling design (cf. Edwards et al. 2005).

In contrast to the total number of macrolichens, the number of threatened macrolichens was not an important predictor for threatened microlichens. The number of threatened macrolichens was only included in the 'macrolichens only model', and in that model the number of macrolichens was more important than the number of threatened macrolichens as indicated by the higher standardized regression coefficient of the latter. The low performance of the number 
of threatened macrolichens as predictor in the regression models may be caused by its low variability. Numbers of threatened macrolichens per plot only varied between 0 and 2 , and they were found in only 19 plots out of 222. The number of threatened microlichens, however, varied between 0 and 4 , and 59 plots contained threatened microlichens. Furthermore, ecological differences between the threatened species of the two groups may also affect the predictive power of the number of threatened macrolichens.

Finally, some important environmental variables may have been missed in our study. For example, neither the recent nor the historic landscape context of the plots such as area, shape and spatial configuration of the forest patches could be accounted for. Variables quantifying such characteristics have been shown to affect lichens (Johansson \& Ehrlén 2003; Gignac \& Dale 2005; Ellis \& Coppins 2007). Especially for rare, mainly vegetatively dispersed species such variables could be important (Walser 2004). Furthermore, historical disturbances such as intensive forest management or fires may influence today's distribution of lichen species (Kalwij et al. 2005).

\section{Conclusions}

Field observations are indispensable if microlichen richness is to be estimated. At least field variables and macrolichen richness have to be assessed to predict microlichen richness with some reliability. Climatic variables, however, are of minor importance. To decrease the costs of surveys, it should be tested if technical staff could be trained to sample macrolichens reliably in the field. So far, there is somewhat controversial evidence of the success of such an approach (McCune et al. 1997; Will-Wolf et al. 2002). Species determination could still be done by specialized taxonomists later in the laboratory. Such a strategy is followed in the Swiss biodiversity monitoring for bryophytes (Hintermann et al. 2002).

Modelling of threatened microlichens, however, proved to be difficult and it was not possible to predict reliably their richness; mainly because there are too few observations. Because it seems difficult to train technical staff to sample microlichens (Will-Wolf et al. 2002), specialized taxonomists are necessary to assess these species. However, this may be a problem because the lichen flora is not well known in many parts of the world and because of a lack of lichenologists in many countries (Galloway 1992; Wolseley 1995).

Because in many forests a large proportion of the epiphytic lichen species are microlichens it seems highly relevant to us to consider them in inventories or biodiversity assessments. We expect that our approach is feasible in many other temperate lowland and mountain forests. Biodiversity conservation strategies ignoring these highly specialized organisms are likely to miss their principal aim.

We would like to thank U. Ulmer for providing data on the Swiss forest inventory (Database query from December 21st 2004 of data from the second inventory 1993-95, Swiss Federal Research Institute WSL, Birmensdorf), W. Stahel for advise on statistical analyses, R. Meile for help on database problems, M. Nägeli, P. Duelli and K. Bollman for linguistic aid, and M. Dietrich, M. Frei, U. Groner, C. Keller and I. Roth for gathering the lichen data. S. Werth, H. Hedenäs, and $\mathrm{H}$. Wagner provided valuable comments on earlier drafts of the manuscript.

\section{REFERENCES}

Barkman, J. J. (1958) Phytosociology and Ecology of Cryptogamic Epiphytes. Assen: Van Gorcum \& Comp. N.V.

Beccaloni, G. W. \& Gaston, K. J. (1995) Predicting the species richness of neotropical forest butterfliesIthomiinae (Lepidoptera, Nymphalidae) as indicators. Biological Conservation 71: 77-86.

Bergamini, A., Scheidegger, C., Stofer, S., Carvalho, P., Davey, S., Dietrich, M., Dubs, F., Farkas, E., Groner, U., Karkkainen, K., Keller, C., Lokos, L., Lommi, S., Maguas, C., Mitchell, R., Pinho, P., Rico, V. J., Aragon, G., Truscott, A. M., Wolseley, P. \& Watt, A. (2005) Performance of macrolichens and lichen genera as indicators of lichen species richness and composition. Conservation Biology 19: 1051-1062.

Berglund, H. \& Jonsson, B. G. (2001) Predictability of plant and fungal species richness of old-growth boreal forest islands. Fournal of Vegetation Science 12: 857-866.

Bolliger, J., Bergamini, A., Stofer, S., Kienast, F. \& Scheidegger, C. (2007) Predicting the potential 
spatial distributions of epiphytic lichen species at the landscape scale. Lichenologist 39: 279-291.

Bolliger, J., Kienast, F. \& Zimmermann, N. E. (2000) Risks of global warming on montane and subalpine forests in Switzerland-a modelling study. Regional Environmental Change 1: 99-111.

Brassel, P. \& Brändli, U.-B. (1999) Schweizerisches Landesforstinventar. Ergebnisse der Zweitaufnahmen 1993-1995. Bern: Haupt.

Dietrich, M. \& Scheidegger, C. (1996) The importance of sorediate custose lichens in the epiphytic lichen flora of the Swiss Plateau and the Pre-Alps. Lichenologist 28: 245-256.

Dietrich, M. \& Scheidegger, C. (1997) Frequency, diversity and ecological strategies of epiphytic lichens in the Swiss Central Plateau and the PreAlps. Lichenologist 29: 237-258.

EASAC (2005) A user's guide to biodiversity indicators. London: The Royal Society, http://www. easac.org/.

Edwards, T. C., Cutler, D. R., Zimmermann, N. E., Geiser, L. \& Alegria, J. (2005) Model-based stratifications for enhancing the detection of rare ecological events. Ecology 86: 1081-1090.

Efron, B. \& Tibshirani, R. J. (1993) An Introduction to the Bootstrap. New York: Chapman \& Hall.

Ellis, C. J. \& Coppins, B. J. (2006) Contrasting functional traits maintain lichen epiphyte diversity in response to climate and autogenic succession. Fournal of Biogeography 33: 1643-1656.

Ellis, C. J. \& Coppins, B. J. (2007) 19th century woodland structure controls stand-scale epiphyte diversity in present-day Scotland. Diversity and Distributions 13: 84-91.

Feuerer, T. \& Hawksworth, D. L. (2007) Biodiversity of lichens, including a world-wide analysis of checklist data based on Takhtajan's floristic regions. Biodiversity and Conservation 16: 85-98.

Fortin, M. J. \& Dale, M. R. T. (2005) Spatial Analysis: a Guide for Ecologists. Cambridge: Cambridge University Press.

Galloway, D. J. (1992) Biodiversity: a lichenological perspective. Biodiversity and Conservation 1: 312-323.

Gaston, K. J. (1996) Species richness: measure and measurement. In Biodiversity: a Biology of Numbers and Difference (K. J. Gaston, ed): 77-113. London: Blackwell Science.

Gignac, L. D. \& Dale, M. R. T. (2005) Effects of fragment size and habitat heterogeneity on cryptogam diversity in the low-boreal forest of western Canada. Bryologist 108: 50-66.

Gonseth, Y., Wohlgemuth, T., Sannsonnes, B. \& Buttler, A. (2001) Die Biogeographischen Regionen der Schweiz. Erläuterungen und Einteilungsstandard. Bern: BUWAL.

Gustafsson, L., Appelgren, L., Jonsson, F., Nordin, U., Persson, A. \& Weslien, J. O. (2004) High occurrence of red-listed bryophytes and lichens in mature managed forests in boreal Sweden. Basic and Applied Ecology 5: 123-129.
Hedenås, H., Bolyukh, V. O. \& Jonsson, B. G. (2003) Spatial distribution of epiphytes on Populus tremula in relation to dispersal mode. Fournal of Vegetation Science 14: 233-242.

Hintermann, U., Weber, D., Zangger, A. \& Schmill, J. (2002) Biodiversitäts-Monitoring Schweiz BDM. Zwischenbericht. Bern: Bundesamt für Umwelt, Wald und Landschaft BUWAL.

Holien, H. (1998) Lichens in spruce forest stands of different successional stages in central Norway with emphasis on diversity and old growth species. Nova Hedwigia 66: 283-324.

Hyvärinen, M., Halonen, P. \& Kauppi, M. (1992) Influence of stand age and structure on the epiphytic lichen vegetation in the middle-boreal forests of Finland. Lichenologist 24: 165-180.

Ihlen, P. G., Gjerde, I. \& Saetersdal, M. (2001) Structural indicators of richness and rarity of epiphytic lichens on Corylus avellana in two different forest types within a nature reserve in south-western Norway. Lichenologist 33: 215-229.

Johansson, P. \& Ehrlén, J. (2003) Influence of habitat quantity, quality and isolation on the distribution and abundance of two epiphytic lichens. Fournal of Ecology 91: 213-221.

Kalwij, J. M., Wagner, H. H. \& Scheidegger, C. (2005) Effects of stand-level disturbances on the spatial distribution of a lichen indicator. Ecological Applications 15: 2015-2024.

Lauber, K. \& Wagner, G. (2001) Flora Helvetica. 3rd Edn. Bern: Haupt.

Lawton, J. H., Bignell, D. E., Bolton, B., Bloemers, G. F., Eggleton, P., Hammond, P. M., Hodda, M., Holt, R. D., Larsen, T. B., Mawdsley, N. A., Stork, N. E., Srivastava, D. S. \& Watt, A. D. (1998) Biodiversity inventories, indicator taxa and effects of habitat modification in tropical forest. Nature 391: 72-76.

Löbel, S., Snäll, T. \& Rydin, H. (2006) Species richness patterns and metapopulation processesevidence from epiphyte communities in boreonemoral forests. Ecography 29: 169-182.

McCune, B., Dey, J. P., Peck, J. E., Cassell, D., Heiman, K., Will-Wolf, S. \& Neitlich, P. N. (1997) Repeatability of community data: species richness versus gradient scores in large-scale lichen studies. Bryologist 100: 40-46.

Mittelböck, M. \& Waldhör, T. (2000) Adjustments for $R^{2}$-measures for Poisson regression models. Computational Statistics and Data Analysis 34: 461-472.

Montgomery, D. C., Peck, E. A. \& Vining, G. G. (2001) Introduction to Linear Regression Analysis. New York: John Wiley \& Sons, Inc.

Negi, H. R. \& Gadgil, M. (2002) Cross-taxon surrogacy of biodiversity in the Indian Garhwal Himalaya. Biological Conservation 105: 143-155.

Ochsner, F. (1927) Studien über die Epiphytenvegetation der Schweiz (insbesondere des schweizerischen Mittellandes). Fahrbuch der St. Gallischen Naturwissenschaftlichen Gesellschaft 63: 1-108. 
Pharo, E. J. \& Beattie, A. J. (1997) Bryophyte and lichen diversity: a comparative study. Australian fournal of Ecology 22: 151-162.

Pharo, E. J., Beattie, A. J. \& Pressey, R. L. (2000) Effectiveness of using vascular plants to select reserves for bryophytes and lichens. Biological Conservation 96: 371-378.

Purvis, W. (2000) Lichens. Washington: Smithsonian Institution Press.

$\mathrm{R}$ Development Core Team (2006) R: A Language and Environment for Statistical Computing. Vienna: R Foundation for Statistical Computing.

Scheidegger, C., Clerc, P., Dietrich, M., Frei, M., Groner, U., Keller, C., Roth, I., Stofer, S. \& Vust, M. (2002) Rote Liste der gefährdeten Baum- und erdbewohnenden Flechten der Schweiz. Bern: BUWAL, WSL \& Conservatoire et Jardin botaniques de la Ville de Genève.

Schmit, J. P., Mueller, G. M., Leacock, P. R., Mata, J. L., Wu, Q. \& Huang, Y. (2005) Assessment of tree species richness as surrogate for macrofungal species richness. Biological Conservation 121: 99-110.

Schulze, C. H., Waltert, M., Kessler, P. J. A., Pitopang, R., Shahabuddin, Veddeler, D., Mühlenberg, M., Gradstein, S. R., Leuschner, C., SteffanDewenter, I. \& Tscharntke, T. (2004) Biodiversity indicator groups of tropical land-use systems: Comparing plants, birds, and insects. Ecological Applications 14: 1321-1333.

Sillett, S. C., McCune, B., Peck, J. E., Rambo, T. R. \& Ruchty, A. (2000) Dispersal limitations of epiphytic lichens result in species dependent on oldgrowth forests. Ecological Applications 10: 789-799.

Sokal, R. R. \& Rohlf, F. J. (1995) Biometry. 3rd Edn. New York: W. H. Freeman and Company.

Stahel, W. (2002) Statistische Datenanalyse. Eine Einführung für Naturwissenschaftler. 4th Edn. Wiesbaden: Vieweg Verlag.

Stierlin, H.-R., Brändli, U.-B., Herold, A. \& Zinggeler, J. (1994) Schweizerisches Landesforstinventar. Anleitung für die Feldaufnahmen der Erhebung 1993-1995. Birmensdorf: Eidgenössische Forschungsanstalt für Wald, Schnee und Landschaft.
Stofer, S., Bergamini, A., Aragón, G., Carvalho, P., Coppins, B. J., Davey, S., Dietrich, M., Farkas, E., Kärkkäinen, K., Keller, C., Lökös, L., Lommi, S., Máguas, C., Mitchell, R., Pinho, P., Rico, V. J., Truscott, A. M., Wolseley, P., Watt, A. \& Scheidegger, C. (2006) Species richness of lichen functional groups in relation to land use intensity. Lichenologist 38: 331-353.

Uliczka, H. \& Angelstam, P. (1999) Occurrence of epiphytic macrolichens in relation to tree species and age in managed boreal forest. Ecography 22: 396-405.

Walser, J. C. (2004) Molecular evidence for limited dispersal of vegetative propagules in the epiphytic lichen Lobaria pulmonaria. American fournal of Botany 91: 1273-1276.

Werth, S., Tommervik, H. \& Elvebakk, A. (2005) Epiphytic macrolichen communities along regional gradients in northern Norway. Fournal of Vegetation Science 16: 199-208.

Will-Wolf, S., Geiser, L., Neitlich, P. N. \& Reis, A. H. (2006) Forest lichen communities and environment-how consistent are relationships across scales? Fournal of Vegetation Science 17: 171-184.

Will-Wolf, S., Scheidegger, C. \& McCune, B. (2002) Methods for monitoring biodiversity and ecosystem function. Monitoring scenarios, sampling strategies and data quality. In Monitoring with Lichens-Monitoring Lichens (P. L. Nimis, C. Scheidegger \& P. A. Wolseley, eds): 147-162. Dordrecht: Kluwer.

Wolseley, P. A. (1995) A global perspecitve on the status of lichens and their conservation. Mitteilungen der Eidgenössischen Forschungsanstalt für Wald, Schnee und Landschaft 70: 11-27.

Wolters, V., Bengtsson, J. \& Zaitsev, A. S. (2006) Relationship among the species richness of different taxa. Ecology 87: 1886-1895.

Zimmermann, N. E. \& Kienast, F. (1999) Predictive mapping of alpine grasslands in Switzerland: Species versus community approach. Fournal of Vegetation Science 10: 469-482. 